ISSN 2078-6441. Вісник Львівського університету. Серія географічна. 2013. Випуск 41. С. 180-192. Visnyk of the Lviv University. Series Geography. 2013. Issue 41. P. 180-192.

911.53:504.5

\author{
рин ур єв ${ }^{1}$, рин ог ${ }^{2}$, юдмил орокін ${ }^{2}$, лекс ндр олубцов² \\ 1 нститут геохімї, мінер логії $m$ рудоутворення ім. . . емененк кр їни, \\ просп. к демік лл дін, 34,03680,м. иїв, кр їн, \\ e-mail: igmr@igmof.gov.ua \\ 2 нститут геогр фї̈ кр їни, \\ вул. олодимирськ , 44, 01034, м. иїв-034, кр їн , \\ e-mail:geo-ins@kiev.ldc.net
}

$\mathrm{x}$ р ктеризов но основні риси л ндш фтної структури одільських овтр у меж х ернопільської обл. прикл ді двох ключових ділянок, що м ють різне господ рське використ ння, про н лізов но вміст в жких мет лів у грунтовому покриві л ндш фтів. ндш фтн структур досліджув ної території т вміст основних з бруднюв чів у грунт х сх р ктеризов ні з результ т ми вл сних польових досліджень.

лючові слов : л ндш фти, одільські овтри, нтропогенний вплив, в жкі мет ли.

овтрове п смо є своєрідною п м'яткою геологічного минулого, н логів якому нем є не лише в меж х одільської височини, й у вропі з г лом. ро унік льність його походження, різном ніття флори т ф уни, б г тство мінер льно-сировинної б зи, м льовничість л ндш фтів є чим ло публік цій ( еренчук ., 1948; ов лишин ., плун ., 1998; рус к ., 2002; ліяр ., 2002; оск люк ., 2006, 2008; ліяр ., пелюх ., 2008; ивий ., ов лишин ., 2008). мість р ціон льного використ ння природних т історико-культурних рекре ційних ресурсів одільських овтр, розвитку лікув льно-оздоровчої сфери, н л годження туристичної інфр структури, збільшення кількості природно-з повідних об’єктів відбув ється руйнув ння т дегр д ція непересічних л ндш фтів через їхне неефективне господ рське використ ння. озитивним було створення в меж х ернопільської обл. природного з повідник “е едобори” у 1991 р., щоб охороняти т ч стково відновлюв ти л ндш фтне різном ніття товтр. дн к нтропогенн порушеність л ндш фтів овтрового п см продовжується вн слідок збільшення кількості т розрост ння поселень, прокл д ння тр нспортної мережі, створення штучних водойм; н йбільший вплив м ють гірничорудн промисловість, лісогоспод рське виробництво і м сшт бне сільськогоспод рське освоєння $[1,10,12]$.

роцеси нтропогеніз ції вносять певні корективи у просторову диференці цію л ндш фтних комплексів, їхній скл д і фізико-хімічні вл стивості, у х р ктер мігр ційних процесів і перерозподіл хімічних елементів, сполук (природних і техногенних).

$m$ мет - визн чення вмісту в жких мет лів у л ндш фт х товтр, що підляг ють різному господ рському використ нню, т кож н ліз л ндш фтних передумов їхньої л тер льної т р ді льної мігр ції.

б'єктом дослідження обр но одільські овтри у меж х ернопільської обл. ослідження проводили н ключових ділянк х, що репрезентують по-різному нтропо-

(C) ур єв ., ог ., орокін ., олубцов ., 2013 
генно змінені л ндш фти овтрового п см . ерш ключов ділянк $\mathrm{x}$ р ктеризує л ндш фтні комплекси бічних товтр у меж х ернопільського р-ну (див. рис. 1). овтри тут повністю розор ні. рім того, тут є н йбільший в обл сті л шівський полігон твердих побутових відходів. руг ключов ділянк (у устинському р-ні) охоплює природний з повідник “ едобори”, де збереглися л ндш фти із зон льним типом рослинного покриву (широколистяні ліси). о ключової ділянки т кож н леж ть прилеглі території - перев жно грол ндш фти (див. рис. 2). ослідження в меж х цієї ділянки викон ні з підтримки співробітників природного з повідник “ едобори”. трим ні результ ти - х р ктеристик л ндш фтів, л ндш фтн т л ндш фтно-геохімічн к pти - перед но у з повідник для використ ння в н уковій роботі.

труктурно-функціон льн неоднорідність л ндш фтних комплексів, різні типи вз ємодій і н прями мігр ційних потоків зумовлюють нерівномірний перерозподіл хімічних елементів і сполук у л тер льному т р ді льному н прям х. тер льні мігp ційні потоки пов'язують геохімічно спряжені системи типу втономний л ндш фтпідлеглий л ндш фт т сприяють просторовій неоднорідності л ндш фтних комплексів. цьому р зі р ді льн неоднорідність л ндш фтних комплексів відобр ж є х р ктер вз ємодії т співвідношення між компонент ми і блок ми типу грунт-грунтотворн пород , грунт-рослин тощо [9]. и дослідили з кономірності л тер льного т $\mathrm{p}$ дільного перерозподілу в жких мет лів у грунт х як основних скл дових л ндш фтних комплексів, де процеси м соенергоперенесення відбув ються з н йбільшою інтенсивністю. ля цього використ но результ ти н лізів проб грунтів, відібр них під ч с проведення польових л ндш фтозн вчо-геохімічних досліджень у ернопільській обл. у 2008-2010 pp.

р зки грунту для вивчення л тер льного перерозподілу в жких мет лів відбир ли з верхнього гумусного горизонту методом “конверт" i, з звич й, по л ндш фтногеохімічній $\mathrm{K}$ тені. н літичні роботи з визн чення в лового вмісту хімічних елементів викон но методом спектр льного н лізу н спектрогр фі СТ -1 в нституті геохімії, фізики мінер лів т рудоутворення ім. . . емененк кр їни. ріоритетність н лізу в лової форми перебув ння хімічних елементів у грунт х є випр вд ною, оскільки вон $\mathrm{x}$ р ктеризує їхній геоекологічний ст н і потенційну небезпеку з бруднення л ндш фтних комплексів, бо геохімічно нерухомі чи м лорухомі елементи ст новлять 3 грозу в р зі їхнього н гром дження т зрост ння концентр ції.

кономірності н гром дження в жких мет лів можн визн чити в р зі з стосув ння коефіцієнт концентр ції, який ілюструє співвідношення вмісту хімічного елемент в гумусовому горизонті досліджув них грунтових розрізів т його фонового зн чення [5].

онові геохімічні п р метри грунтів отрим но з літер турними джерел ми [11]. нтерпрет цію т н ліз розр хов них коефіцієнтів концентр ції $\mathrm{Pb}, \mathrm{Co}, \mathrm{Mn}, \mathrm{Cu}, \mathrm{Mo}, \mathrm{Cr}, \mathrm{Ni}$ викон но н л ндш фтних з с д х. ндш фтозн вчі дослідження обр ної території $€$ б зовими для викон ння з вд нь л ндш фтозн вчо-геохімічного т геоекологічного змісту. они грунтуються н методичних доробк х л ндш фтозн вств ( идин ., 1962; еренчук ., укурудз ., 1977; учков ., ковск я ., 2004) із використ нням суч сних методів л ндш фтного геоінформ ційного к ртогр фув ння ( видчук . т ін., 2004, 2005). ля території дослідження з результ т ми вл сних польових досліджень т 3 використ нням фондових м тері лів створено великом сшт бні л ндш фтні к рти (м сшт 6 1:50 000), н яких відобр жено л ндш фтні комплекси р нгу урочищ.

роби для дослідження р ді льного перерозподілу в жких мет лів відбир ли з основних генетичних горизонтів грунтового профілю. ході інтерпрет ції отрим них н лі- 
тичних д них щодо перерозподілу хімічних елементів і сполук по грунтовому профілю використ но кількісні зн чення їхнього вмісту без порівняння з фоновими пок зник ми, оскільки т кі пок зники визн чено лише для верхнього гумусного горизонту грунтів.

міст в жких мет лів у л ндш фтних комплекс $x$ біля л шівського поліго$\boldsymbol{н}$ твердих побутових відходів. л шівський полігон твердих побутових відходів один із н йпроблемніших техногенних об'єктів ернопільської обл. олігон розт шов ний з 25 км н північ від ернополя в меж х бічної товтри і з йм $є$ н йвище місцеположення у рельєфі (див. рис. 1). ндш фтн структур н вколишньої території предст влен горбистими т сл бкогорбистими підвищеними межирічними рівнин ми (340-400 м), що скл дені лесоподібними суглинк ми (див. рис. 1, виділи 4, 7). грунтовому покриві перев ж ють темно-сірі опідзолені легко- і середньосуглинкові грунти т чорноземи регр дов ні середньосуглинкові. явність високих поверхонь т схилів бічних товтр (виділи $2,3,11,13,14$ ), широких з пл в р. ерет т їі допливів (виділ 46), густої ерозійної мережі, що предст влен 6 лк ми і лощин ми, зумовлюють скл дність т контр стність будови цієї території. ндш фтні комплекси, у яких відібр но зр зки грунту, включно з урочищ ми бічних товтр, використовують як гроугіддя, урочищ вододільної поверхні (виділ 3) т схилу овтрового п см (11) з йняті к р'єром, який уже не використовують.

ля грол ндш фтів, які є в меж х впливу л шівського сміттєзв лищ, основний з бруднюв ч - свинець. оновий вміст свинцю у грунт х 3 лежить від його концентp ції в м теринських пород х. оловним техногенним джерелом його потр пляння у л ндш фтні комплекси є промислові підприємств і тр нспорт. ід підприємств кольорової мет лургії у л ндш фти потр пляють мінер льні сполуки свинцю ( $\mathrm{PbS}, \mathrm{PbO}$, $\left.\mathrm{PbSO}_{4}, \mathrm{PbO} \mathrm{PbSO}_{4}\right)$, з бруднення від тр нспорту відбув ється у формі г логенових солей $\left(\mathrm{PbBr}_{2}, \mathrm{PbBrCl}, \mathrm{Pb}(\mathrm{OH}),(\mathrm{PbO}) \mathrm{PbBr}_{2}\right)$ [3]. полуки свинцю м лорозчинні, i, відповідно, їм вл стив невисок мігр ційн зд тність. ігрує Рb перев жно в скл ді орг нічних комплексів т мех нічним способом із глинистими ч стинк ми [8]. озчинність цього елемент знижується в нейтр льному і лужному середовищ х [3], тобто відбув ється його кумуляція.

підст ві н лізу результ тів дослідження л тер льного перерозподілу свинцю з зн чимо, що н йменш його концентр ція з фіксов н у днищ х б лок (точки пробовідбору 111-08, 232-10, 239-10), грунтовий покрив яких предст влений, відповідно, дерновими опідзоленими глеюв тими середньо- т в жкосуглинковими н митими, дерновими глейовими середньосуглинковими і дерновими к рбон тними глейовими середньосуглинковими н митими грунт ми. им грунт м вл стив нейтр льн бо сл бкокисл ре кція грунтового розчину, одн к в ловий вміст свинцю тут є в меж х фону.

копичення свинцю не відбув ється, оскільки урочищ б лок м ють вир жені тр нзитні вл стивості. томість 3 фіксов ні перевищення фонових концентр цій $\mathrm{Pb}$ у грунт х вододільних поверхонь, схилів і лощин. ого рівень досяг є 20-60 мг/кг, н точк x 99-08 і 231-10 виявлено т кож перевищення , що для в лового вмісту свинцю ст новить 32 мг/кг [6,7]. исокі пок зники вмісту свинцю у проб х грунтів, відібр них у з пл ві т днищі б лки (відповідно, точки 112-08, 231-10), незв ж ючи н х р ктерні для них тр нзитні умови мігр ції. е з свідчує скл дність і $б$ г тоф кторність мех нізмів первинного т вторинного розподілу з бруднюв чів, тр нсформ ції вмісту і форм хімічних елементів з лежно від л ндш фтної структури території, її геохімічних і мігp ційних вл стивостей. ожн припустити про перев жну роль у цьому вип дку процесів первинного н дходження з бруднюв чів. 


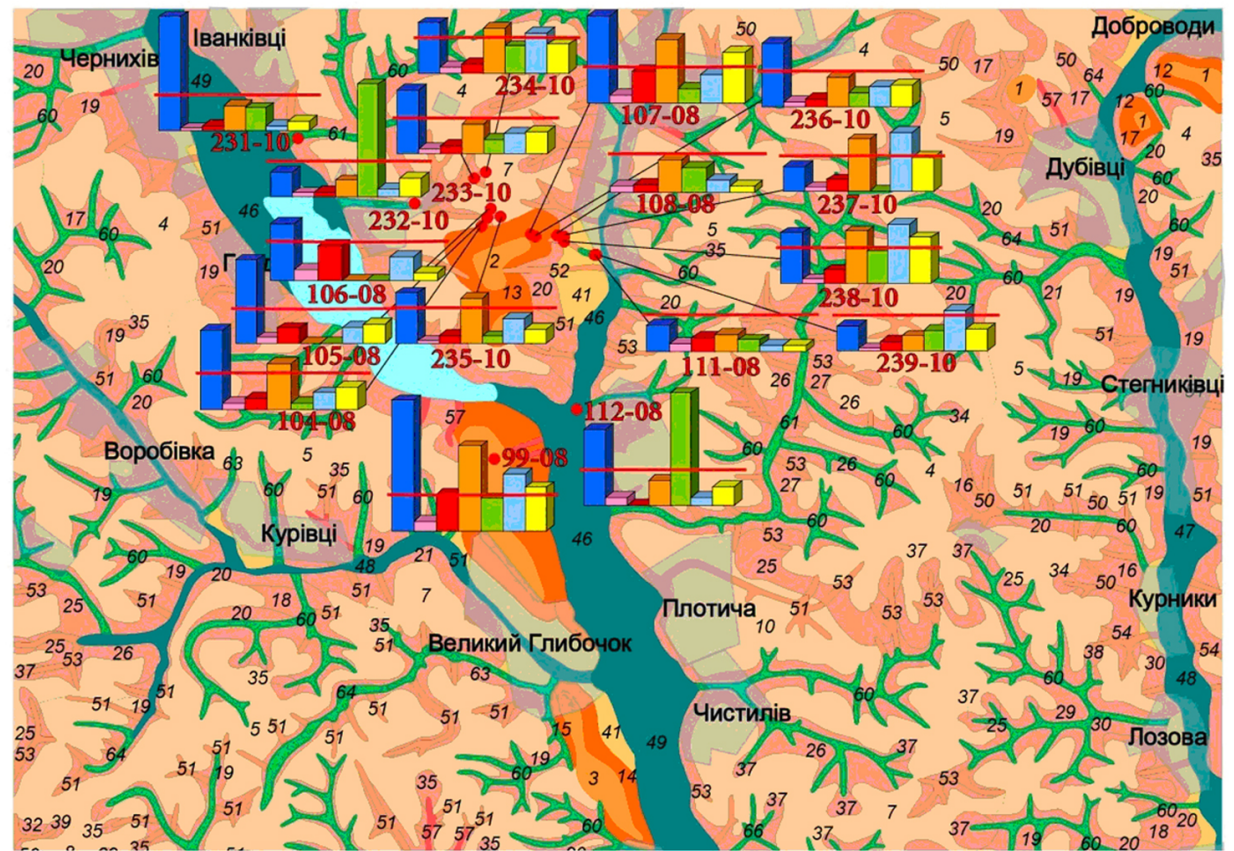
107-08 точка відбору проби ґрунту для визначення
вмісту важких металів та її номер

Ландшафтні комплекси: (друге число в номері - рік відбору проби)

Коефіцієнти концентрації важких металів у пробах ґрунту

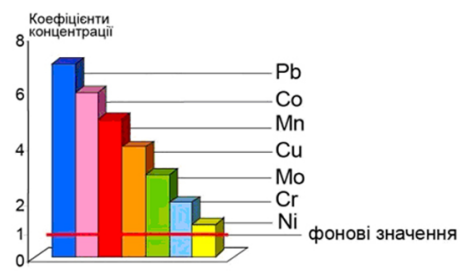

Біла Населені пункти

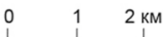

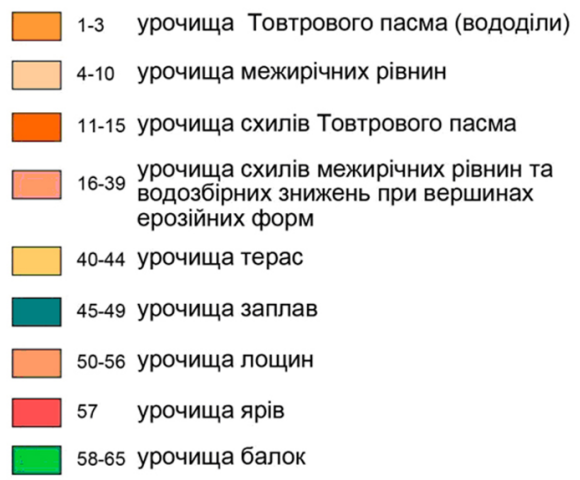

1-65 індекси ландшафтних урочищ

ис. 1. міст в жких мет лів у л ндш фтних комплекс х біля л шівського полігон твердих побутових відходів. 


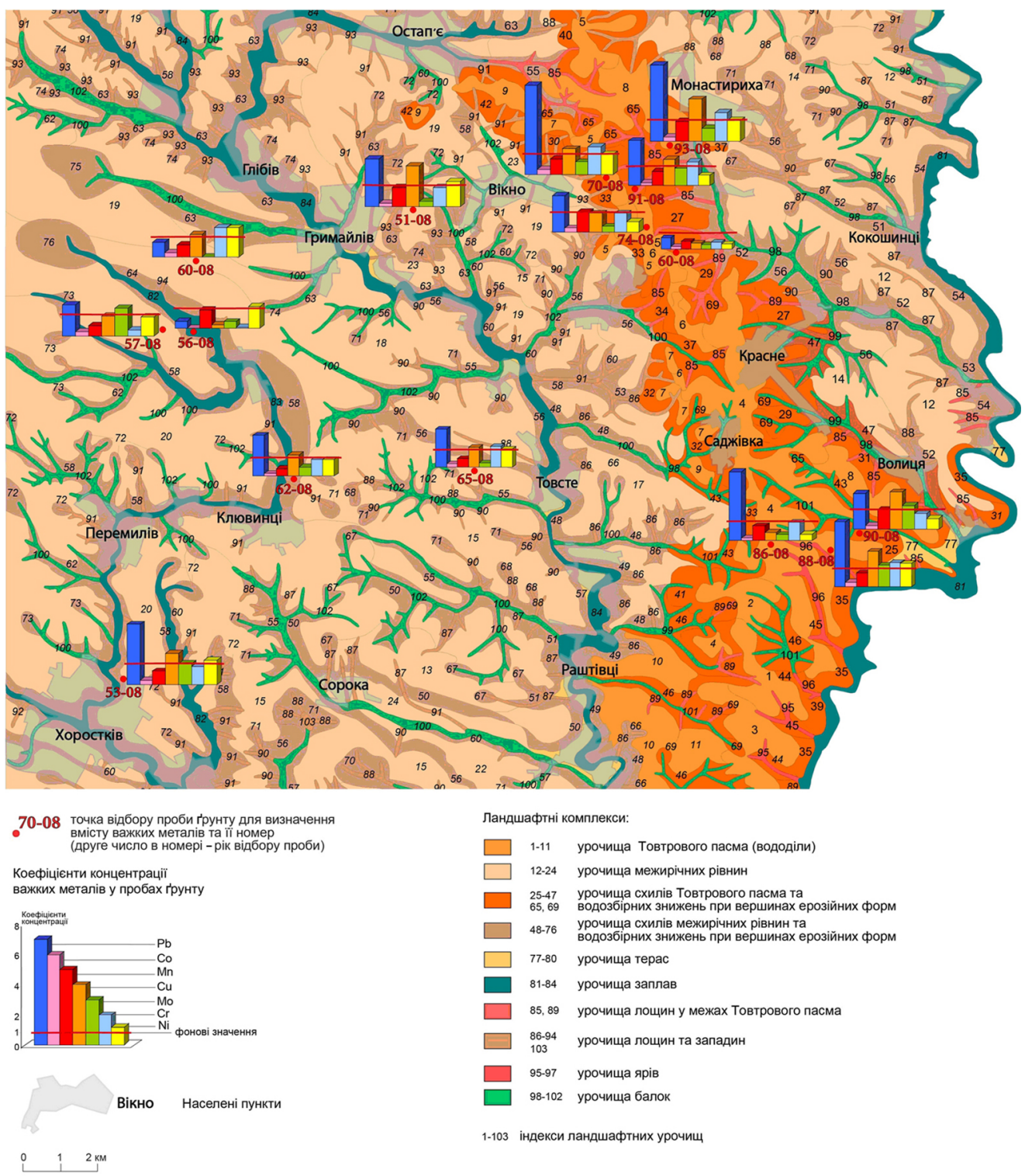

ис. 2. міст в жких мет лів у л ндш фтних комплекс $x$ природного 3 повідник “ едобори” т прилеглих територій.

еред досліджув них в жких мет лів зн чні пок зники концентр ції у грунт х цієї території м є т кож мідь. оновий вміст цього елемент в грунт х 3 лежить від його вмісту у м теринській породі т від грунтотворних процесів. тіони міді хімічно ктивні т зд тні до хімічної вз ємодії з мінер льними й орг нічними компонент ми грунту.

мігр ційні вл стивості вплив ють процеси дсорбції, оклюзії, хел то- і комплексоутворення т мікробіологічної фікс ції. д тність грунтів утримув ти мідь у зв'яз ному 
чи розчиненому ст ні з лежить від х р ктеру і кількості орг нічних сполук (гумінові т фульвокислоти утворюють стійкі комплекси з іон ми u), мінер льного скл ду грунту (процеси дсорбції міді пов’яз ні з н явністю в грунті оксидів $\mathrm{Fe} \mathrm{i} \mathrm{Mg}$, морфних гідроксидів Fe i Al т глинистих мінер лів). ізн в лентність міді визн ч є з лежність їі мігр ційних вл стивостей від окисно-відновних умов $[3,8]$.

ожн т кож простежити з лежності л тер льної мігр ції міді від л ндш фтної структури території. отрим ними д ними, мідь пр ктично не н копичується в лощин х (точки 105-08, 233-10), $б$ лк х (111-08, 239-10, 231-10), з пл в х (112-08). к виняток - перевищення фонових зн чень вмісту міді виявлено у проб х грунтів, відібр них у верхів'ях лощин (точки 234-10, 235-10). йвищий рівень концентр ції міді (50 мг/кг) 3 фіксов но н вершині бічної товтри (точк 99-08, н пр вобережжі р. ерет) т у верхній ч стині схилу товтри (точк 107-08, лівобережжя р. ерет, поблизу полігон побутових відходів). нші схили межирічних рівнин теж вирізняються підвищеним вмістом міді у грунтовому покриві, одн к концентр ція цього елемент не перевищує вст новлені норми н жодній із точок пробовідбору (для міді в лового вмісту скл д $є 55 \mathrm{мг/кг}[6,7])$.

ловий вміст коб льту т м нг ну в усіх про н лізов них зр зк х є в меж х фону. езн чний вміст молібдену, з винятком проб грунтів, відібр них у з пл ві (точк 112-08) т днищі б лки (точк 232-10), де концентр ція Мо сяг є 10 мг/кг. озчинність сполук молібдену з лежить від кислотно-лужного середовищ грунтів. більшення кислотності грунтів, зб г чення їх гідроксид ми люмінію, 3 ліз т люмінієм і м нг ном призводить до різкого зменшення мігр ційних вл стивостей [3]. ізикохімічні вл стивості молібдену т кож визн ч $є$ форм перебув ння елемент в грунті. сновні його в лентні ст ни $-+4 \mathrm{i}+6$. полуки Мо ${ }^{6+}$ добре розчинні, особливо в лужному середовищі, тоді як сполуки $\mathrm{Mo}^{4+}$ сл бкорозчинні. мови н копичення молібдену в л ндш фтних комплекс $\mathrm{x}$ із тр нзитними мігр ційними умов ми т $\mathrm{p}$ середовищем грунту, близьким до нейтр льного (точки 112-08 т 232-10), потребують дет льнішого дослідження.

е виявлено зн чного перевищення фонових пок зників хрому т нікелю у грунт х л ндш фтних комплексів, що перебув ють у зоні впливу л шівського полігон твердих побутових відходів. собливо небезпечним потенційним з бруднюв чем $є$ хром. ок зники вмісту хрому в грунті з леж ть від м теринських порід, одн к н суч сному ет пі збільшення концентр ції сполук хрому у верхньому гумусному горизонті грунту пов'яз не з техногенним впливом, зокрем через промислові відходи і стічні води. еохімічні вл стивості хрому, як і більшості в жких мет лів, з леж ть головно від ступеня його окислення т кислотно-лужних умов. грунт х н явний перев жно $\mathrm{Cr}^{3+}$, сполуки якого в сл бкокислому середовищі м лорухливі, при p 5,5 м йже повністю вип д ють в ос д [3]. ебезпечнішим є хром зі ступенем окиснення +6 , оскільки це к нцероген першого кл су небезпеки [2], що є мігр ційно ктивним і в кислих, і в лужних грунт х [3].

кономірності р ді льного перерозподілу в жких мет лів по генетичних горизонт х х р ктерних для цієї території грунтів, які з зн ють зн чного нтропогенного н в нт ження, досліджено н прикл ді точок комплексного опису 237-10 т 238-10. очки 3 кл дено в середній ч стині схилу т в центр льній ч стині днищ глибокої лощини, поряд з якою розміщене сміттєзв лище. трьох верхніх грунтових горизонт х, відповідно, чорнозему опідзоленого середньосуглинкового сл бкозмитого н лесоподібних суглинк х т чорнозему опідзоленого глеюв того н митого середньо- 
суглинкового н делюві льних суглинк х, що підстелені лесоподібними суглинк ми, відібр но зр зки грунту. рис. 3 пок з но грунтові профілі, їхні х р ктеристики т в ловий вміст у грунтових горизонт х основних хімічних з бруднюв чів території: $\mathrm{Pb}$, $\mathrm{Cu}, \mathrm{Cr}, \mathrm{Ni}$. досліджув них грунтових профілях з фіксов но подібні тенденції р ді льного перерозподілу в жких мет лів. прикл д, вміст свинцю зрост є вниз по профілю. ідь з звич й кумулюється у верхньому горизонті грунту, що пояснюють нтропогенним впливом, т кож її біо кумуляцією [3]. е підтверджене і н шими дослідженнями. илуговуються т кож сполуки хрому р зом із низхідними поток ми вологи. міст нікелю пр ктично не змінюється по профілю досліджених грунтових розрізів.

ведені д ні щодо розподілу з бруднюв чів у грунтовому покриві л ндш фтів $є$ прикл дом, який ілюструє кту льність т кого н лізу, особливо для грол ндш фтів. ібр ні в ході дослідження польові м тері ли д ють змогу дет льніше вивчити з кономірності р ді льної мігр ції з бруднюв чів.

остовірність і коректність отрим них н ми н літичних д них підтверджено повторними відбор ми, зробленими у 2008 т 2010 рр. точк х дослідження, у яких відібр но проби в ці роки у меж х тих с мих л ндш фтних урочищ і розт шов них поряд, збережено розмірність і співвідношення між вмістом хімічних елементів.

г лом з бруднення в жкими мет л ми є х р ктерним для полігонів твердих побутових відходів [4]. я проблем кту льн й для л шівського сміттєзв лищ, яке експлу тують з порушенням природоохоронних т с ніт рних норм. ході польових досліджень ми з фіксув ли прикл ди необдум ного і нер ціон льного господ рюв ння. міттєзв лище розт шов не н вершині бічної товтри, в пнякові т крейдові відкл ди якої можуть сприяти ктивній р ді льній мігр ції з бруднюв чів т проникненню їх у водоносні горизонти. ирокі й глибокі лощини н його схил х є потенційними шлях ми перенесення з бруднюв чів з поверхневими і грунтовими вод ми,

т кож повітряним шляхом. прикл д, одн 3 т ких лощин (у ній з кл дені точки пробовідбору 107-08, 108-08, 236-238-10) “відкрив ється” до с. гровиця, мешк нці якого ч сто відчув ють сморід від сп люв ного н полігоні сміття, який спуск ється до сел . протилежному, з хідному від сміттєзв лищ н прямі лощини виходять до в чівських ст вків н р. ерет, звідки з бир ють води для потреб ернополя. $\mathrm{p}$ ж $\epsilon$ т кож те, що територію у безпосередній близькості від л шівського полігону, який ніяк не обл дн ний і не відокремлений, розорюють і використовують як гроугіддя.

p діусі сотень метрів н вколо нього поля вкриті сміттям, яке розносить вітер.

міст в жких мет лів у л ндш фтних комплекс $x$ природного $з$ повідник “ едобори” $m$ прилеглих сільськогоспод рських територій. ододіли у меж х 3 повідник предст влені урочищ ми оловного п см овтр т бічних товтр (див. рис. 2, виділи 1-11). н чну ч стину території оловного п см 3 йм ють урочищ основної поверхні високого (380-400 м) і середнього (340-380 м) рівнів. они скл дені в пняковими відкл д ми, що перекриті лесоподібними суглинк ми різної потужності. грунтовому покриві перев ж ють дернові к рбон тні м лопотужні легкосуглинкові грунти, н вищих поверхнях - ясно-сірі т сірі легко- і середньосуглинкові. мови місцезрост ння цих урочищ - свіжодібровні, тепер вони з йняті дубово-гр бовими ліс ми т перелог ми. оширені т кож відкриті ділянки, для яких х р ктерні суходібровні умови місцезрост ння т які вкриті ч г рник ми і сухотр вною рослинністю. 

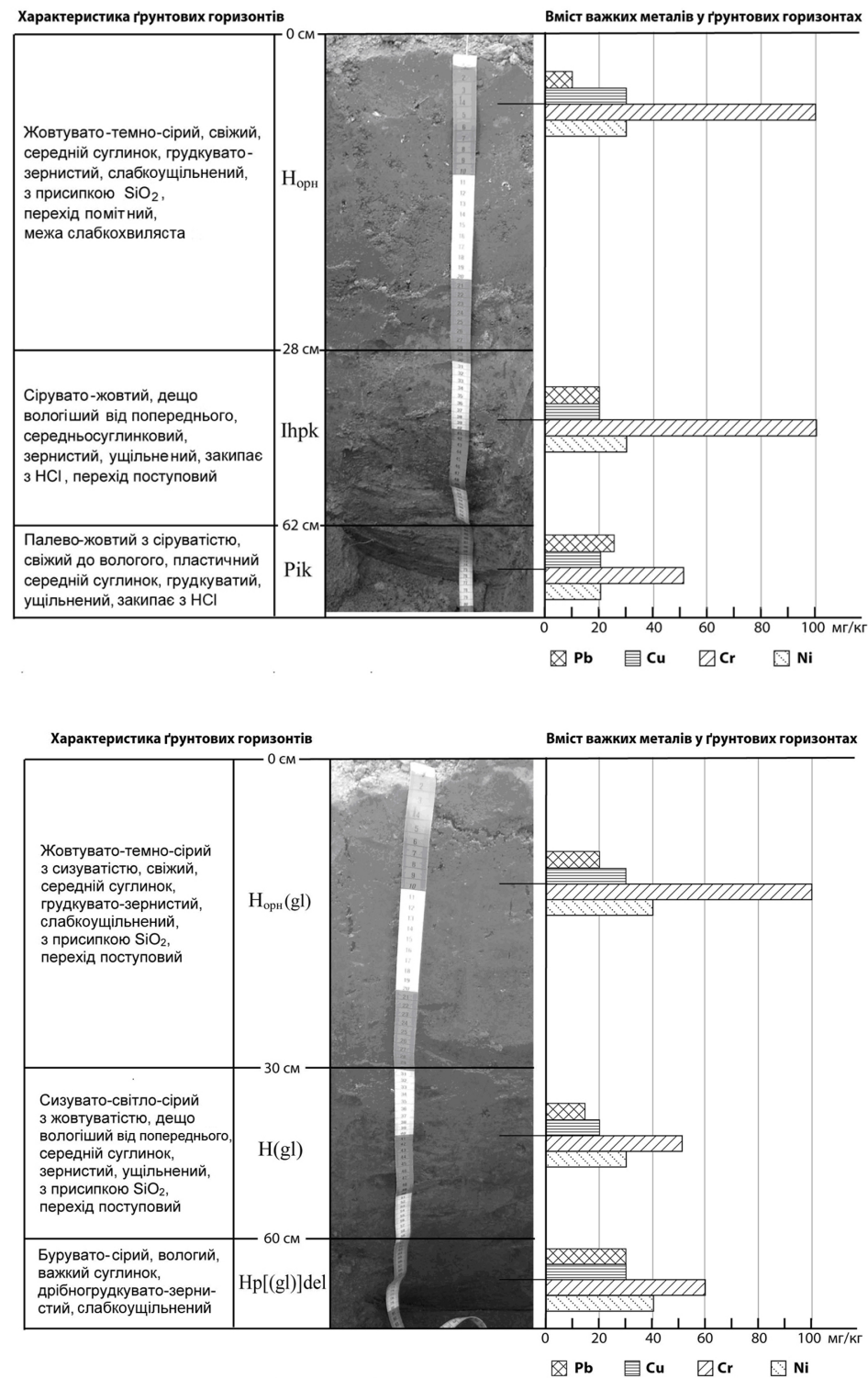

ис. 3. ді льний перерозподіл в жких мет лів по генетичних горизонт х чорнозему опідзоленого середньосуглинкового сл бкозмитого н лесоподібних суглинк х, н схилі лощини ( ) т чорнозему опідзоленого глеюв того н митого середньосуглинкового н делюві льних суглинк х, що підстелені лесоподібними суглинк ми, у днищі лощини ( ).

ндш фтні комплекси бічних товтр теж предст влені урочищ ми високого (380-400 м) т середнього (340-380 м) рівня (виділи 7, 9). они гостровершинні бо опуклі зі скелястими виход ми щільних к рбон тних порід, скл дені в пняковими від- 
кл д ми, н яких сформов ні дернові к рбон тні сильнозмиті легкосуглинкові т ясносірі й сірі легкосуглинкові грунти. ерев ж є суходібровний тип місцезрост ння, т кі урочищ з йняті сухотр вно-різнотр вними лук ми, ч стково - ч г рник ми із глоду, шипшини, свидини, ялівцю, для урочищ зі свіжо- т вологодібровними умов ми зволоження х р ктерні дубово-гр бові й соснові ліси культурного походження.

хилові урочищ відокремлюють овтри від нижчих поверхонь прилеглих територій. они є доволі різном нітними з експозицією, крутістю, підстильними пород ми, тип ми грунтів тощо (виділи 25-42). руті т сильносп дисті схили головно з хідної т південно-з хідної експозицій. е схили скл дного профілю (опукло-ввігнуті, ступінч сті), скл дені в пняковими пород ми, які перекрив є несуцільний покрив лесоподібних суглинків, з сірими і темно-сірими середньо- т в жкосуглинковими різного ступеня змитості грунт ми. мови місцезрост ння т ких схилів перев жно суходібровні, вони 3 йняті ч г рник ми із глоду, шипшини, свидини т ялівцю, тонконогово-типч ковими степовими угрупов ннями. п дисті т похилі схили вологіші. они скл дені потужнішим ш ром лесоподібних суглинків, н яких сформув лись сірі т темно-сірі середньосуглинкові грунти. ослинний покрив предст влений дубово-буково-гр бовими ліс ми з домішкою ясен , черешні.

езн чну площу з йм ють урочищ $б$ лок т річкових долин. нищ $б$ лок скл дені делювієм, грунтовий покрив доволі різном нітний - він предст влений лучними н митими ок рбон ченими середньосуглинковими грунт ми, лучно-чорноземними опідзоленими середньосуглинковими т лучно-болотними середньосуглинковими грунт ми; умови місцезрост ння - сиродібровні, суч сний рослинний покрив - вільшняки, сирі дубово-гр бові ліси т вологотр вні луки.

ндш фтні комплекси, прилеглі до овтрового п см , у меж х якого розт шов ний природний з повідник “ едобори”, вирізняються нижчими висотними позн чк ми у рельєфі, бсолютні висоти сяг ють близько 300-330 м. оверхня плоск , сл бкохвиляст, злегк н хилен н південь і південний схід. рельєфі домінують пл корні сл бкохвилясті межиріччя, широкі неглибокі річкові долини.

ля досліджув ної території х р ктерне поширення хвилястих межиріч, скл дених лесоподібними суглинк ми. оновими є порівняно знижені ( бсолютні висоти 300-330 м) сл бкохвилясті межирічні рівнини, з чорнозем ми типовими потужними м логумусними середньосуглинковими, яким вл стиві свіжодібровні умови місцезрост ння, перев жно розор ні, ч стково - під перелог ми (виділ 15). кі межиріччя формують основну поверхню між н селеними пункт ми оростків, ленівк, лещ в . они відмежов ні підвищеною порівняно з н вколишньою територією місцевістю, що м є н зву “рим йлов огил” (н йвищ точк у пї меж х - 336,4 м). е фр гмент опуклої, сл бкохвилястої вододільної рівнини, розт шов ної між н селеними пункт ми оділля, ородниця, ст п’є, еж нівк, рим йлів (виділ 19). оверхня скл ден лесоподібними суглинк ми з чорнозем ми типовими потужними м логумусними т чорнозем ми типовими м логумусними к рбон тними середньосуглинковими, умови місцезрост ння свіжодібровні.

ежиріччя рік олодні ст ви т нил з йняте сл бкогорбистими пологон хиленими рівнин ми, що скл дені лесоподібними суглинк ми з темно-сірими опідзоленими середньосуглинковими грунт ми, чорнозем ми опідзоленими середньосуглинковими т чорнозем ми регр дов ними (виділи $13,15,22)$. північний з хід від с. овсте територія ст є більш вирівняною, із м йже плоскими пл корними поверхнями (18). 
хили межиріч (виділи 39-49) перев жно похилі (крутістю 3-5) т сл бкосп дисті $\left(5-7^{\circ}\right)$, у грунтовому покриві домінують т кі с мі грунтові відміни, як і в урочищ $\mathrm{x}$ основних поверхонь. ериторія розчленов н мережею лощин, б лок, м лих річок, що н леж ть головно до б сейну р. нил .

і л ндш фтні комплекси з зн ли суттєвого нтропогенного перетворення. исок природн родючість земель, сприятливі клім тичні умови зумовили зн чне їхнє сільськогоспод рське освоєння.

території грол ндш фтів, прилеглих до природного з повідник “ едобори”, невисокий вміст в жких мет лів у грунт х. фіксов но перевищення фону лише в лового вмісту свинцю т міді. онцентр ції коб льту, м нг ну, молібдену, хрому т нікелю не досяг ють бо є близькими до їхніх фонових пок зників. ловий вміст досліджув них хімічних елементів перебув є у меж х , лише н точці 53-08 з фіксов но вміст $\mathrm{Pb}$ у грунті 40 мг/кг, що є вищим від пок зник . г лом пробовідбір грунтових зр зків викон но н вододільних поверхнях т у верхніх ч стин х схилів вододільних рівнин, тому з умов одн кового рівня нтропогенного н в нт ження т схожої л ндш фтної структури вміст відповідних хімічних елементів у грунт х грол ндш фтів суттєво не відрізняється. ігр ційн структур досліджув ної ділянки сприяє перев ж нню процесів винесення з ч стковою кумуляцією хімічних елементів, у тому числі в жких мет лів. ктивне вилуговув ння в жких мет лів з фіксов но лише н точці комплексного спостереження 53-08, що х р ктеризує урочище з пл ви, якій вл стиві тр нзитні мігр ційні умови.

н логічні тенденції простежено і для території природного з повідник “ едобори" - суттєві перевищення фону з фіксов ні лише для свинцю т міді. дн к пр ктично н всіх точк х відбору проб у меж х $з$ повідник концентр ція свинцю в грунт х $є$ вищою від гр ничнодопустимих рівнів. е, очевидно, пов'яз не 3 втодорогою регіон льного зн чення ернопіль- т нів, що проходить через ікнянське т ородницьке лісництв , які з йм ють північну і центр льну ч стини з повідник . ля території овтрового п см х р ктерний дещо підвищений вміст м нг ну порівняно 3 прилеглими грол ндш фт ми. к ж 3 кономірність виявлен і для опис них вище бічних овтр, що перебув ють у зоні впливу л шівського полігону твердих побутових відходів (див. рис. 1, точки 99-08 т 107-08). жерелом н дходження м нг ну в грунтовий комплекс $є$ основні грунтоутворюв льні породи. копичується м нг н перев жно у верхньому гумусному горизонті, що пов'яз но з його фікс цією орг нічними сполук ми.

кож підвищен концентр ція м нг ну простежується у горизонт х, зб г чених оксид ми і гідроксид ми з ліз . нг н у грунт х перебув є у вигляді оксидів і гідроксидів, які утворюють конкреції різного ді метр бо входять до скл ду грунтових ч стинок.

розчинність м нг ну в грунтовому розчині н йбільше вплив ють окисно-відновні т кислотно-лужні умови середовищ [3]. йбільш мігр ційно ктивний м нг н у відновному нейтр льному і лужному середовищі. умов окисного середовищ відбув ється окиснення $\mathrm{Mn}^{2+}$ до $\mathrm{Mn}^{3+}, \mathrm{Mn}^{4+}$ т перехід їх у нерозчинний ст н [8].

тже, відмінні види нтропогенного н в нт ження н територію овтрового п см м ли б визн ч ти різні рівні хімічного з бруднення. одноч с н ліз вмісту в жких мет лів у грунтовому покриві л ндш фтів обр них ключових ділянок не виявив суттєвих відмінностей у зн ченнях вмісту досліджув них елементів. вдяки порівнянню пок зників в лового вмісту в жких мет лів у грунтовому покриві л ндш фтних комплексів овтр, які підляг ють ктивному сільськогоспод рському освоєн- 
ню (див. рис. 1), т л ндш фтних комплексів природного 3 повідник “ едобори" (див. рис. 2) виявлено близькі зн чення рівнів з бруднення ними.

еред досліджув них хімічних елементів н йпоширенішим з бруднюв чем для л ндш фтів обох ключових ділянок є свинець. к уже з зн чено, високий вміст свинцю можн обгрунтув ти н явністю втошляхів н території “ едоборів” чи використ нням сільськогоспод рської техніки н гроугіддях, що з йняли бічні горби у північній ч стині одільських овтр. чевидно, причиною високого вмісту свинцю може бути й порівняно нед внє (з 1991 р.) з пров дження режиму з повід ння н цій території, як до того ч су перебув л в лісогоспод рському використ нні. вколо л шівського сміттєзв лищ виявлені дещо вищі порівняно з територією природного з повідник “ едобори” т прилеглих земель рівні вмісту міді, хрому і модібдену. ідвищені рівні вмісту міді, хрому, нікелю у л ндш фтних комплекс х овтрового п см , можливо, спричинені не лише н дходженням 3 місцевих джерел з бруднення, й процес ми тр нскордонного перенесення з бруднюв чів, оскільки підвищен територія овтр є б р'єром н шляху повітряних мігр нтів, що підтверджене незн чним вмістом цих хімічних елементів у грунт х прилеглих територій.

ведені дослідження підтвердили з лежність перерозподілу в жких мет лів від л ндш фтної структури території, мігр ційних умов т фізико-хімічних вл стивостей грунтів. дн к скл дн природн орг ніз ція л ндш фтних комплексів т нтропогенне втруч ння в них можуть призвести до порушення з г льновизн них 3 кономірностей, що теж виявлено в ході дослідження. е підтверджує кту льність т необхідність проведення систем тичних досліджень л ндш фтних комплексів з різною інтенсивністю господ рського використ ння.

\section{СПИСОК ВИКОРИСТАНОЇ ЛІТЕРАТУРИ}

1. олік . . нтропогенн тр нсформ ція природи з повідник “ едобори” т прилеглих територій впродовж ХХ століття / . . олік, . . винко, . . ем'янчук // хорон і менеджмент об'єктів неживої природи н 3 повідних територіях : м тері ли міжн р. н ук.-пр кт. конф. (смт рим йлів, 21-23 тр вня 2008 р.). - рим йлів; ернопіль : жур , 2008. - .54-57.

2. ступ до медичної геології / [3 ред. . . удьк, . . д менк ]. - . : к демпрес, 2010. - .1.- $736 \mathrm{c.}$

3. $\sigma m-е н д и c$. икроелементы в почв х и р стениях / . б т - енди с, . енди с ; пер. с нгл. - . : ир, 1989. - 439 с.

4. улинич . . $з$ ємодія фільтр тів полігонів твердих побутових відходів ( ) із зоною ер ції (еколого-геохімічн оцінк ) : втореф. дис. н здобуття н ук. ступеня к нд. геол. н ук : 21.06.01. - ., 2007. - 19 с.

5. лищев . . еохімія л ндш фтів / . . лишев . - . : ибідь, 2000. - 472 с.

6. етодик грохімічної п спортиз ції земель сільськогоспод рського призн чення / [з ред. . . ижук , . . ісового, . . енц ровського]. - . : ибк моя, 2003. $-61 \mathrm{c}$.

7. тик . . гроекологічний моніторинг т п спортиз ція сільськогоспод рських земель / . . тик , . . p ріко. - . : ітосоціоцентр, 2002. - 296 с.

8. ерельм н. . еохимия / . . ерельм н. - . : ысш. шк., 1989. - 528 с. 
9. ерельм н . . еохимия л ндш фт / . . ерельм н, . . симов. - . : стрея, 1999. - 768 с.

10. ивий . . ехногенн тр нсформ ція північно-з хідної ч стини одільських овтр (в меж х 6 р зького р йону) / . . ивий, . . вришок // хорон і менеджмент об'єктів неживої природи н $з$ повідних територіях : м тері ли міжн р. н ук.-пр кт. конф. (смт рим йлів, 21-23 тр вня 2008 р.). - рим йлів; ернопіль : жур , 2008. - . 271-275.

11. оновий вміст мікроелементів у грунт х кр їни / [3 ред. . . тєєв , . . щенко]. - рків, 2003. - 71 с.

12. рик . . ункціон льн роль овтрового кряжу і природного з повідник “ едобори" у н ціон льній т регіон льній екомереж х / . . рик, . . рик // хорон і менеджмент об'єктів неживої природи н 3 повідних територіях : м тері ли міжн р. н ук.-Пр кт. конф. (смт рим йлів, 21-23 тр вня 2008 р.). рим йлів; ернопіль: жур , 2008. - .318-324.

m ття:н дійшл до ред кцї̈ 18.10.2012

доопр цьов н 25.12.2012

прийнят до друку 20.02.2013

\title{
LANDSCAPES OF PODILLIAN TOVTRY AND THEIR POLLUTION WITH HEAVY METALS
}

\author{
Iryna Kuraeva $^{1}$, Iryna Roga ${ }^{2}$, Liudmyla Sorokina ${ }^{2}$, Olexandr Holubtsov ${ }^{2}$ \\ ${ }^{1}$ M. P. Semenenko Institute of Geochemistry, Mineralogy and Ore Formation, \\ Acad. Palladina Ave., 34, UA - 03680 Kyiv, Ukraine, \\ e-mail:igmr@igmof.gov.ua \\ ${ }^{2}$ Institute of Geography of the National Academy of Sciences of Ukraine, \\ Volodymyrska Str., 44, UA - 01034 Kyiv-034, Ukraine, \\ e-mail:geo-ins@kiev.ldc.net
}

The main features of landscape structure of Podillian Tovtry within the territory of Ternopil region are considered. The content of heavy metals in the soils of the landscapes is analysed by the example of two key areas with different types of landuse. The landscape structure of the territory and the content of heavy metals in soils have been characterized on the basis of results of the authors' field research.

Key words: landscapes; Podillian Tovtry; anthropogenic impact; heavy metals. 
рин ур ев ${ }^{1}$, рин ог ${ }^{2}$, одмил орокин ${ }^{2}$, лекс ндр олубцов²

1 нститут геохимии, минер логии и рудообр зов ния им. . . емененко кр ины,

$$
\begin{aligned}
& \text { просп. к демик лл дин, 34,03680, г. иев, крин, } \\
& \text { e-mail: igmr@igmof.gov.ua } \\
& 2 \text { нститут геогр фии кр ины, } \\
& \text { ул. л димирск я, 44, 01034, г. иев-034, кр ин, } \\
& \text { e-mail: geo-ins@kiev.ldc.net }
\end{aligned}
$$

$\mathrm{x}$ р ктеризов но основные черты л ндш фтов одольских олтр в предел х ернопольской обл. примере двух ключевых уч стков с р зными вид ми хозяйственного использов ния про н лизиров но содерж ние тяжелых мет ллов в почвенном покрове л ндш фтов. ндш фтную структуру исследуемой территории и содерж ние основных з грязнителей в почв $\mathrm{x}$ ох $\mathrm{p}$ ктеризов но по результ т м собственных полевых исследов ний.

лючевые слов : л ндш фты, одольские олтры, нтропогенное воздействие, тяжелые мет ллы. 